\title{
Examining Patent Examination
}

\author{
Mark A. Lemley \& Bhaven Sampat ${ }^{1}$
}

The United States Patent and Trademark Office ("PTO") receives more applications today than it ever has before. What happens to those applications? Patent prosecutors all have stories and personal experiences. Until quite recently, however, this sort of "anecdata" was all that was available, because the law prevented anyone from ever finding out what happened to patent applications that did not ultimately issue as patents.

That changed in 2001, when the PTO began publishing data on pending applications, and when the Patent Application Information Retrieval ("PAIR") system allowed the public to track the fate of those applications in real time. In this paper, we use those changes to reportfor the first time ever-systematic data on the fate of applications submitted to the PTO. We are able to confirm much received wisdom, but also to offer some surprising results.

\section{Our Data ${ }^{2}$}

\footnotetext{
${ }^{1}$ @ 2010 Mark A. Lemley \& Bhaven Sampat. Mark A. Lemley is the William H. Neukom Professor at Stanford Law School and a partner with the firm of Durie Tangri LLP. Bhaven Sampat is a Professor of Health Policy and Management at the Columbia School of Public Health.

We thank Patrick Crosby at xblabs.com for assistance in obtaining the data used in our analyses and John Allison, Ernie Beffel, Miriam Bitton, Colleen Chien, Chris Cotropia, Lawrence Ebert, Jeanne Fromer, Bill Gallagher, Rose Hagan, Joe Miller, Roberta Morris, David O’Brien, Michael Risch, Kathy Strandburg, two anonymous reviewers, and participants in workshops at Stanford Law School, UMKC Law School, the IP Scholars' Conference, the NYU Conference on Empirical Legal Studies, Microsoft Corporation, and the Advanced Patent Law Institutes in Austin, Texas, and San Jose, California, for comments on an earlier draft..

${ }^{2}$ The description in this section is taken from our companion study, Mark A. Lemley \& Bhaven Sampat, Is the Patent Office a Rubber Stamp?, 58 EMORY L.J. 181 (2008).
} 
We identified a group of patent applications and followed them through the process. Specifically, we collected every original utility patent application filed in the month of January 2001 that was published by April 2006. After eliminating plant, design, and reissue patents, Patent Cooperation Treaty ("PCT") applications directed at foreign filing, and continuations, divisionals, and continuation-in-part ("CIP") applications based on earlier applications, we were left with 9,960 applications. We then collected every "transaction" for each of these patent applications-every filing or act by the patentee and every action by the PTO-from the PTO's PAIR database as of April 2006.

Our approach has the advantage that for those applications it can give us accurate, verifiable data on the questions that have vexed patent lawyers and policy-makers. Until 1999, our approach was impossible, because patent applications were not published unless and until they issued as patents. But beginning with applications filed this millennium, the vast majority of patent applications are published 18 months after they are filed, and most of the rest 60 months after filing. ${ }^{3}$ For each of these applications, we can determine whether a continuation of any type was filed, and whether the application (and any of its continuation "children") was ultimately patented, was abandoned without any continuation being filed, ${ }^{4}$ or was still pending more than five years after the original application was filed.

Our use of PAIR data has other significant advantages. Because we collected all the transaction data, we can report a wealth of data about the way the PTO treats applicationshow many receive first-action allowances, how many patents are allowed after rejection, and so

\footnotetext{
${ }^{3} 35$ U.S.C. § 122(b) (setting out the rule and describing the exceptions, chiefly for applicants who agree not to file counterpart applications abroad).

${ }^{4}$ There is no actual way for the PTO to finally reject a patent. See Mark A. Lemley \& Kimberly A. Moore, Ending Abuse of Patent Continuations, 84 B.U. L. REV. 63, 64 (2004). We consider a patent application to have been finally abandoned if the applicant has filed a notice of abandonment or has not responded to a PTO rejection for over six months and has not filed an appeal or any form of continuation.
} 
forth. We can also track the significant differences in the treatment of applications by area of technology. ${ }^{5}$

\section{Results}

The transaction data from the PAIR records give us a window on the patent prosecution

process. Prosecution is an ex parte negotiation between the applicant and the examiner. The applicant files an application. The examiner can either grant the patent or reject it. If the examiner rejects it, the applicant can either "traverse" the rejection, i.e. argue against it, or amend the claims to seek a patent on a generally narrower variation of the original claims. The examiner can again either allow the claim or reject it. That second rejection is typically called a "final" rejection, but in fact the applicant has an opportunity to amend the claims again, to seek an interview to persuade the examiner in person, to file a continuation, or to appeal.

Overwhelmingly, the first reaction a patent examiner has to an application is a non-final rejection. As Table 1 shows, $86.5 \%$ of the PTO's first office actions were non-final rejections.

\footnotetext{
${ }^{5}$ While our approach has a number of advantages, one significant disadvantage is that we sample only published applications. If the characteristics of published applications are systematically different than those of unpublished applications, this would limit our ability to make inferences from our sample to the broader population. Applications granted or abandoned before 18 months do not appear in our analyses unless the applicant affirmatively chose to ask for early publication. Data from granted patents suggests that about $17 \%$ of patents are granted before 18 months; of these, about half (46\%) are published pre-grant. It is likely that some applications are finally abandoned before 18 months have passed, and never show up either in the dataset or as issued patents. A more serious issue is that even applications pending for more than 18 months can "opt-out" of publication if they don't have corresponding foreign applications, or if they have corresponding foreign applications but also have priority dates pre-dating the effective date of the AIPA. See 35 U.S.C. § 122(b)(2)(B) (opt out for U.S.only applications); American Inventors Protection Act of 1999, Pub. L. No. 106-113 (transition period implementing publication for applications with priority dates after November 2000). If opt-out is systematically related to characteristics of interest, our conclusions could be biased. In exploring this issue, we found that while opt-out of publication is non-randomly distributed across applications, our main conclusions are not affected if we consider only the subsample of applications for which opt-out was not possible. This gives us some confidence that the missing data doesn't skew our results in a systematic way.
} 
Only a tiny percentage $(0.04 \%)$ began with final rejections, ${ }^{6}$ and $13.5 \%$ granted patents on the first office action without any argument or negotiation.

Table 1: Distribution of first office actions

\begin{tabular}{|l|l|l|}
\hline First Office Action & Number of Applications & Share of Applications \\
\hline Final Rejection & 4 & $0.04 \%$ \\
\hline Mail Notice of Allowance & 1324 & $13.46 \%$ \\
\hline Non-Final Rejection & 8511 & $86.50 \%$ \\
\hline Total & $9839^{7}$ & $100.00 \%$ \\
\hline
\end{tabular}

But the second time appears to be a charm. After that initial, non-final rejection, a significant number of applications resulted in patents. As we have shown elsewhere, over $70 \%$ of applications ultimately issue as patents. ${ }^{8}$ Table 2 divides applications into those that received a final rejection and those that did not. Table 2 demonstrates that almost three-fourths of the applications that did issue (73.1\%) did so without ever receiving a "final" rejection.

Table 2: Relationship between notices of allowance and final rejections

\begin{tabular}{|l|l|l|l|}
\hline Received a Final & No Notice of Allowance & Notice of Allowance & Total \\
Rejection & Number & Number & Number \\
& Row \% & Row $\%$ & Row $\%$ \\
& Column $\%$ & Column $\%$ & \\
& & & \\
\hline
\end{tabular}

\footnotetext{
${ }^{6}$ Examiners are not supposed to issue a final rejection on the first office action, see Manual of Patent Examining Procedure $\S 706.07(b)\left(8^{\text {th }}\right.$ ed. 2001) (providing for final rejection on first office action only for continuation applications, which we have excluded from our data set), so this reflects either errors in the data set or mistakes by the examiners.

${ }^{7}$ This number (9839) differs from the total number of applications above (9960) because a small number of applications never received a first office action at all, generally because they were abandoned before any action by the PTO.

${ }^{8}$ Lemley \& Sampat, supra note 2 , at 192.
} 


\begin{tabular}{|c|c|c|c|}
\hline No & $\begin{array}{l}1571 \\
24.0 \% \\
50.1 \%\end{array}$ & $\begin{array}{l}4986 \\
76.0 \% \\
73.1 \%\end{array}$ & $\begin{array}{l}6557 \\
100.0 \% \\
65.9 \%\end{array}$ \\
\hline Yes & $\begin{array}{l}1563 \\
46.0 \% \\
49.9 \%\end{array}$ & $\begin{array}{l}1833 \\
54.0 \% \\
26.9 \%\end{array}$ & $\begin{array}{l}3396 \\
100.0 \% \\
34.1 \%\end{array}$ \\
\hline Total & $\begin{array}{l}3134 \\
31.5 \% \\
100.0 \%\end{array}$ & $\begin{array}{l}6819 \\
68.5 \% \\
100.0 \%\end{array}$ & $\begin{array}{l}9953 \\
100.0 \% \\
100.0 \%\end{array}$ \\
\hline
\end{tabular}

In addition to the widespread allowance by the second office action, there were also a significant number of applications-1,833-that ultimately were allowed by the PTO but had at one point been "finally" rejected. The term "final rejection," then, is a classic legal misnomer. ${ }^{9}$ Indeed, as Table 3 demonstrates, more than half of those applications that received a final rejection had ultimately resulted in patents, and another $20 \%$ were still pending after more than five years.

Table 3: Status of applications with "final" rejections

\begin{tabular}{|l|l|}
\hline Status & Number \\
& Column \% \\
\hline Abandoned & 900 \\
& $26.5 \%$ \\
\hline
\end{tabular}

\footnotetext{
${ }^{9}$ Robert P. Merges et al., Intellectual Property in the New Technological Age 160 (rev. 4th ed. 2007).
} 


\begin{tabular}{|l|l|}
\hline Patented & $1798^{10}$ \\
& $52.9 \%$ \\
\hline Pending & 698 \\
& $20.6 \%$ \\
\hline Total & 3396 \\
& $100.0 \%$ \\
\hline
\end{tabular}

To see the significance of these numbers, consider that the chance of having your patent application finally abandoned is only slightly greater for those applications that received a final rejection than those that did not $(26.5 \%$ for those with a final rejection compared to $24.6 \%$ in the overall sample). And $18 \%$ of applications with final rejections had continuation applications pending as of April 2006, so they may also result in one or more patents despite the final rejection.

Why do patents result from applications which received "final" rejections? Sometimes this change of outcome reflects a change of heart-the applicant has persuaded the PTO to issue the same claims that it initially rejected. Other times, it is because the patentee has amended the claims, generally but not necessarily narrowing them to avoid prior art. Many of these applications were amended after the initial rejection, so the PTO process may have the effect of narrowing unduly broad claims. To study this, we determined whether the applications were amended before issuance. Based strictly on the PAIR classification data, it appears that quite a few patents-significantly more than half of those issued-issued without any amendment. But we worried that these fields may have understated the number of

\footnotetext{
${ }^{10}$ This number (1798) differs slightly from the number receiving a Notice of Allowance in Table 2 (1833) because some applications had been allowed but had not yet issued as patents at the time of our study.
} 
amendments, ${ }^{11}$ particularly those after non-final office actions. The transaction history also includes information on "Response After Non-Final Office Action," and many of those responses involve amendments. However, this field could indicate other responses too, in addition to amendments. To check this we examined the file wrappers for a random sample of 100 transactions coded in PAIR as involving a "Response to Non-Final Office Action" but where PAIR did not list an amendment. It turns out that 94 of those 100 in fact included amendments. If we include the "Responses to Non-Final Office Actions" in the list of applications amended, the numbers change dramatically, as Table 5 illustrates:

Table 4: Status of applications, by whether they were ever amended (upper bound)

\begin{tabular}{|l|l|l|l|}
\hline Status & Never Amended & At Least One & Total \\
& Number & Amendment & \\
& Row \% & Number & Number \\
& 1193 & 1251 & Row \% \\
\hline Abandoned & $48.81 \%$ & $51.19 \%$ & 2444 \\
\hline Patented & 969 & 5693 & $100.0 \%$ \\
\hline Pending & $14.55 \%$ & $85.45 \%$ & 6662 \\
& 49 & 798 & $100.0 \%$ \\
\hline Total & $5.79 \%$ & $94.21 \%$ & $100.0 \%$ \\
\hline
\end{tabular}

${ }^{11}$ We thank Lawrence Ebert for raising this concern. Lawrence Ebert, More on Patent Grant Rate; the USPTO Is NOT a Rubber Stamp, IPBIZ, Aug. 2, 2007, http://ipbiz.blogspot.com/2007/08/more-on-patent-grant-rate-uspto-is-not.html. 
These numbers suggest that the vast majority of applicants, particularly the applicants who obtain patents and those who are still actively trying to do so, do so in part by amending their claims in response to examiner concerns. That in turn may be a hopeful sign for patent examination: even though the PTO ultimately grants patents on a large majority of the applications it receives, it may still be serving an important gatekeeper function by requiring applicants to narrow their claims. (This assumes that most of those amendments narrow the claims; that seems likely, but we cannot test it empirically).

Table 5 shows that after a final rejection, patents are much more likely to be rejected (or abandoned) if the applicant does not amend (13.6\% abandoned for amended applications versus $50.0 \%$ abandoned for unamended applications). The difference does not reflect significant differences in pendency of applications with and without amendments after final rejections, but rather differences in the propensity of such applications to be patented: of the applications which were eventually patented after a final rejection, $80.6 \%$ were amended while $19.4 \%$ were not:

Table 5: Status of applications, amended and not amended after receiving "final rejections"

\begin{tabular}{|l|l|l|l|}
\hline Status & No Amendment After & Amended After Final & Total \\
& Final Rejection & Rejection & \\
& Number & Number & Number \\
& Row \% & Row \% & Row \% \\
\hline Column \% & Column \% & Column \% \\
\hline & 601 & 299 & 900 \\
& $50.0 \%$ & $33.2 \%$ & $13.6 \%$ \\
\hline
\end{tabular}




\begin{tabular}{|l|l|l|l|}
\hline Patented & 348 & 1450 & 1798 \\
& $19.4 \%$ & $80.6 \%$ & $100.0 \%$ \\
& $29.0 \%$ & $66.1 \%$ & $52.9 \%$ \\
\hline Pending & 252 & 446 & 698 \\
& $36.1 \%$ & $63.9 \%$ & $100.0 \%$ \\
\hline Total & $21.0 \%$ & $20.3 \%$ & $20.6 \%$ \\
& 1201 & 2195 & 3396 \\
& $35.4 \%$ & $64.6 \%$ & $100.0 \%$ \\
& $100.0 \%$ & $100.0 \%$ & $100.0 \%$ \\
\hline
\end{tabular}

This is consistent with the gatekeeper hypothesis noted above. If an examiner issues a final rejection, an applicant is likely to overcome that rejection only by amending the claims, presumably to narrow them or otherwise correct a deficiency the examiner perceived.

Besides amendment, a second strategy applicants have for responding to a final rejection is the examiner interview. Because interviews are not recorded, and because examiner records of interviews almost never include any useful information, interviews are often thought by practitioners to be a way to explain the invention (and perhaps make concessions) without creating prosecution history that binds the applicant in later litigation. Interviews can also be initiated by examiners to clarify a rejection, discuss how it may be overcome, or otherwise expedite prosecution.

Table 6 shows that interviews are primarily associated with applications that received final rejections:

Table 6: Interviews and final rejections

\begin{tabular}{|l|l|l|l|}
\hline Received Final & Never Had & Had Interview & Total \\
\hline
\end{tabular}




\begin{tabular}{|l|l|l|l|}
\hline Rejection & Interview & Number & Number \\
& Number & Row \% & Row \% \\
& Column \% & Column \% & Column \% \\
\hline No & 5981 & 576 & 6557 \\
& $91.2 \%$ & $8.8 \%$ & $100.0 \%$ \\
\hline Yes & $69.5 \%$ & $42.9 \%$ & $65.8 \%$ \\
& 2630 & 766 & 3396 \\
& $77.4 \%$ & $22.6 \%$ & $100.0 \%$ \\
& $30.5 \%$ & $57.1 \%$ & $34.1 \%$ \\
\hline Total & 8611 & 1342 & $100.0 \%$ \\
& $86.5 \%$ & $13.5 \%$ & 9953 \\
& $100.0 \%$ & $100.0 \%$ & \\
\hline
\end{tabular}

Table 7 shows that of the 766 cases with an interview and a final rejection, 591 (77.2\%) had the interview after the final rejection. Moreover, applicants who interview with an examiner after a final rejection are more likely to obtain a patent and less likely to abandon their application than those who do not:

Table 7: Outcome of interview after final rejection

\begin{tabular}{|l|l|l|l|}
\hline Status & $\begin{array}{l}\text { No Interview After } \\
\text { Final Rejection } \\
\text { Number } \\
\text { Column \% }\end{array}$ & $\begin{array}{l}\text { Interview After Final } \\
\text { Rejection } \\
\text { Number } \\
\text { Column \% }\end{array}$ & $\begin{array}{l}\text { Total } \\
\text { Column \% }\end{array}$ \\
\hline Abandoned & 790 & 110 & 900 \\
$18.6 \%$ & $26.5 \%$ \\
\hline
\end{tabular}




\begin{tabular}{|l|l|l|l|}
\hline Patented & 1428 & 370 & 1798 \\
& $50.9 \%$ & $62.6 \%$ & $52.9 \%$ \\
\hline Pending & 587 & 111 & 698 \\
& $20.9 \%$ & $18.8 \%$ & $20.6 \%$ \\
\hline Total & 2805 & 591 & 3396 \\
& $100.0 \%$ & $100.0 \%$ & $100.0 \%$ \\
\hline
\end{tabular}

While $50.9 \%$ of applications with a final rejection but no interview were eventually patented, $62.6 \%$ of those with an interview after final rejection were patented. (Note that almost all of the difference comes from a reduced percentage of abandoned applications, and not from any significant change in the percentage of pending applications. ${ }^{12}$ ) These numbers would seem to suggest that interviews do work. But they could also reflect that applicants (or even examiners) more committed to getting a patent issued are more likely to use interviews.

Finally, the PTO backlog has been so great in this millennium that there are some patent applications that simply haven't been resolved. As noted above, 848 original applications were still pending five and a half years after they were filed. Some of those were still pending because the applicants took actions that extend prosecution-filing a continuation, Continuing Prosecution Application, Request for Continued Examination ("RCE"), or a notice of appeal. Nonetheless, there were 229 applications in our study that were still pending in the PTO even though the applicants have not taken actions. That is a small percentage-only $2.3 \%$-but that there are any such application at all is troubling given that the delay breeds uncertainty for both the applicant and third parties. ${ }^{13}$

\footnotetext{
${ }^{12}$ Linear probability regression shows that an interview after a final rejection raises the probability that an application is patented (as opposed to abandoned or pending) by 13.3 percentage points, after controlling for art unit effects.

${ }^{13} \mathrm{~A}$ few might be subject to government secrecy orders that require delay in prosecution for national security reasons. 35 U.S.C. § 181.
} 


\section{B. The Use of Continuations and RCEs}

\section{Extent and Type of Continuations}

A second important area our data allow us to explore is the use of continuation applications to extend patent prosecution beyond a final rejection by the PTO. Continuations fall into two basic categories: traditional statutory continuations (themselves composed of continuations, continuations-in-part (“CIP"s), and divisionals) $)^{14}$ and Requests for Continued Examination ("RCE"s), a form created more recently to permit continued debate over an application without the filing of an entirely new application. In our data set, $14.4 \%$ of all applications have children (ordinary continuations, CIPs, or divisionals). In addition, $15.9 \%$ of all applications have RCEs. The total number of applications with any sort of continuations is not just the sum of these numbers, because some applications have both children and RCEs. Rather, the total number of applications with at least one form of continuation is $27.3 \% .{ }^{15}$ And that is a floor, not the final number; other applicants with at least one application pending may still file continuations or RCEs.

Table 8: Share of applications with continuations and/or RCEs, by status of parent

\begin{tabular}{|l|l|l|l|}
\hline Status of & Share with & Share & Share with Either \\
Parent & Continuation & with & Continuations or RCEs \\
\hline
\end{tabular}

\footnotetext{
${ }^{14}$ For discussion of the differences between these types of continuations, see our discussion in Lemley \& Sampat, supra note 2, at 184.

${ }^{15}$ Graham and Mowery documented an increase in continuations up until the adoption of the 20-year patent term, and a decrease thereafter. Stuart J.H. Graham \& David C. Mowery, Submarines in Software? Continuations in U.S. Software Patenting in the 1980s and 1990s, 13 ECON. INNOVATION \& NEW TECH. 443 (2004). Our data suggest that the numbers have risen again.
} 


\begin{tabular}{|l|l|l|l|}
\hline Application & & $R C E$ & \\
\hline Abandoned & $13 \%$ & $7 \%$ & $18 \%$ \\
\hline Patented & $16 \%$ & $14 \%$ & $26 \%$ \\
\hline Pending & $7 \%$ & $57 \%$ & $60 \%$ \\
\hline Total & $\mathbf{1 4 \%}$ & $\mathbf{1 6 \%}$ & $\mathbf{2 7 \%}$ \\
\hline
\end{tabular}

Particularly notable here is the large percentage of cases still pending at the time of our study that had an RCE filed, compared with a small number with an ordinary continuation.

Table 9 shows that roughly $30 \%$ of those children were "ordinary" continuations, and slightly less than $40 \%$ were divisionals, with the remainder being CIPs or applications for which we could not determine continuation type:

\section{Table 9: Distribution of continuation types}

\begin{tabular}{|l|l|l|}
\hline Continuation Type & Number & Share of Total \\
\hline Continuation & 608 & $30.2 \%$ \\
\hline Continuation-in-Part & 422 & $21.0 \%$ \\
\hline Divisional & 770 & $38.2 \%$ \\
\hline Unknown/ Not determinable & 216 & $10.7 \%$ \\
\hline Total & 2016 & $100.0 \%$ \\
\hline
\end{tabular}


Table 10 shows that nearly half of these children have themselves already issued as patents, though not surprisingly (given their later filing date) a large percentage of these continuation applications were still pending:

Table 10: Status of child applications ${ }^{16}$

\begin{tabular}{|l|l|l|l|l|}
\hline Continuation Type & Number & Share Abandoned & Share Patented & Share Pending \\
\hline Continuation & 608 & $11.5 \%$ & $43.9 \%$ & $44.6 \%$ \\
\hline Continuation-in- & 422 & $18.5 \%$ & $55.2 \%$ & $26.3 \%$ \\
Part & & & & \\
\hline Divisional & 770 & $10.8 \%$ & $57.0 \%$ & $32.2 \%$ \\
\hline
\end{tabular}

In a previous paper, ${ }^{17}$ we showed that accounting for these continuations had only a small effect on the overall grant rate, because they disproportionately come from parent applications that are themselves patented. That is, the use of these older forms of continuation is primarily to obtain multiple patents from a single base application, not to continue fighting over the issuance of a first patent. Moreover, Table 11 shows that over $80 \%$ of parent applications with patented children were themselves patented.

\footnotetext{
${ }^{16}$ The data on status of child applications is current as of April 2006.

${ }^{17}$ Lemley \& Sampat, supra note 2, at 192.
} 
Table 11: Continuations and Multiple Patents

\begin{tabular}{|c|c|c|c|}
\hline 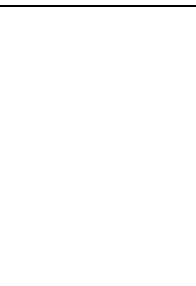 & $\begin{array}{l}\text { No Child Patented } \\
\text { Number } \\
\text { Row \% } \\
\text { Column \% }\end{array}$ & $\begin{array}{l}\text { At Least One Child } \\
\text { Patented } \\
\text { Number } \\
\text { Row \% } \\
\text { Column \% }\end{array}$ & $\begin{array}{l}\text { Total } \\
\\
\text { Number } \\
\text { Row \% } \\
\text { Column \% }\end{array}$ \\
\hline Abandoned & $\begin{array}{l}2313 \\
94.6 \% \\
25.2 \%\end{array}$ & $\begin{array}{l}133 \\
5.4 \% \\
17.3 \%\end{array}$ & $\begin{array}{l}2446 \\
100.0 \% \\
24.6 \%\end{array}$ \\
\hline Patented & $\begin{array}{l}6047 \\
90.7 \% \\
65.8 \% \\
\end{array}$ & $\begin{array}{l}619 \\
9.3 \% \\
80.7 \% \\
\end{array}$ & $\begin{array}{l}6666 \\
100.0 \% \\
66.9 \% \\
\end{array}$ \\
\hline Pending & $\begin{array}{l}833 \\
98.2 \% \\
9.1 \% \\
\end{array}$ & $\begin{array}{l}15 \\
1.8 \% \\
2.0 \%\end{array}$ & $\begin{array}{l}848 \\
100.0 \% \\
8.5 \%\end{array}$ \\
\hline Total & $\begin{array}{l}9193 \\
92.3 \% \\
100.0 \%\end{array}$ & $\begin{array}{l}767 \\
7.7 \% \\
100.0 \% \\
\end{array}$ & $\begin{array}{l}9960 \\
100.0 \% \\
100.0 \% \\
\end{array}$ \\
\hline
\end{tabular}

\section{Success of RCEs and "Ordinary" Continuations}

RCEs have somewhat different characteristics and uses than ordinary continuations.

They are examined almost immediately, rather than going into the general application hopper, so they are not particularly good tools if the patentee's interest is delay. And unlike ordinary continuations, RCEs keep the whole case pending in the office, so they can't be used to take a 
patent on narrow claims and to continue to fight for broad claims; rather, RCEs are primarily useful to continue fighting with an examiner who is reluctant to grant claims. ${ }^{18}$

Does this persistence work? Applicants who used RCEs ultimately got a patent in $59 \%$ of the cases, and, as of April 2006, had RCEs pending in $30.6 \%$ more. Only $10.4 \%$ of the cases with RCEs resulted in abandonment, though, of course, some of the pending RCEs will presumably result in abandonment rather than a patent. This might suggest that the RCE works to change the PTO's mind in many cases. But it is also likely that the grant of a patent in some of these cases results from the applicant changing her mind after filing the RCE and seeking only the narrower claims that the PTO had previously allowed. The answer may be somewhere in between-RCEs allow the examiners and the applicants to come to terms on language narrower than what the applicant argued for but broader than what the examiner was willing to allow in the primary case.

Table 12: Status of applications with RCEs

\begin{tabular}{|l|l|}
\hline Status & Share \\
\hline Abandoned & $10.4 \%$ \\
\hline Patented & $59.0 \%$ \\
\hline Pending & $30.6 \%$ \\
\hline
\end{tabular}

\footnotetext{
${ }^{18}$ Whether this represents wearing down the PTO (hoping for an error in the applicant's favor or for a new examiner with a different view of the merits) or is instead a process pushed by examiners themselves to expand their citation counts, see generally Thomas, supra note (NOTE: Citation for Thomas not found elsewhere.), is impossible to determine in a statistical sense. It would require a baseline judgment as to whether the examiner was "right" to reject each initial application.
} 
By contrast, given the existence of the quicker and simpler RCE, "ordinary" continuations today are primarily useful for those who want multiple patents covering similar technology-perhaps to build a "fence" around a core product, perhaps because they need a narrow patent quickly and are willing to fight for a broader patent later-or who want to delay the resolution of their case, either to surprise the industry or to modify their claims to cover subsequent developments in the technology. ${ }^{19}$ Some evidence for this can be found in Table 12 above, from comparison of the "ordinary" continuations to CIPs and divisionals: a high percentage of the ordinary continuations were still pending $-44.6 \%$, far more than other types of continuations. If the ordinary continuations were not being used in part for delay, we would expect these numbers to be roughly equal or, if anything, for CIPs to be more likely to be pending, since those applications have added new material to the patent and therefore complicate the examination.

More direct evidence of the uses for old-style continuations comes from the finding reported in our prior paper that continuations come disproportionately from the group of applicants who also obtained patents on their original applications. ${ }^{20}$ The number of patented children that come from patented parents far exceeds the proportion of patented parents in the overall population. Some of these patentees have legitimate arguments for broader claims, but were willing to settle for narrower claims in the original application in order to get at least some protection more quickly. Others leave an application pending so they can change their claims when they see what a competitor is doing, or in the hopes that they can get a new examiner with a different view.

\section{Continuations by Industry}

\footnotetext{
${ }^{19}$ For discussion of the different uses of continuations and CIPs, see Deepak Hegde et al., Pioneers, Submariners, or Thicket-Builders: Which Firms Use Continuations in Patenting?, (Nat'I Bureau of Econ. Research, Working Paper No. W13153, 2007).

${ }^{20}$ Mark A. Lemley \& Bhaven Sampat, supra note 2 at 192-93.
} 
Both the frequency with which patent applicants use continuations and the type of continuation they use also differ significantly by industry. We report the share of applications in each art unit that rely on continuations in Table 13.

Table 13: Share of applications with continuations and RCEs, by Art Unit

\begin{tabular}{|l|l|l|l|}
\hline Art Unit & $\begin{array}{l}\text { Share with } \\
\text { Continuations }\end{array}$ & Share with RCE & $\begin{array}{l}\text { Share with Either a } \\
\text { Continuation or } \\
\text { RCE }\end{array}$ \\
\hline $\begin{array}{l}\text { 1600 Biotechnology and Organic } \\
\text { Chemistry } \\
\text { (Art Units 1600-1661) }\end{array}$ & $27 \%$ & $22 \%$ & $43 \%$ \\
\hline $\begin{array}{l}\text { 1700 Chemical and Materials } \\
\text { Engineering } \\
\text { (Art Units 1700-1775) }\end{array}$ & $20 \%$ & $15 \%$ & $30 \%$ \\
\hline $\begin{array}{l}\text { 2100 Computer Architecture, } \\
\text { Software, \& Information Security } \\
\text { (Art Units 2100-2195) }\end{array}$ & $10 \%$ & $27 \%$ & $35 \%$ \\
\hline $\begin{array}{l}\text { 2600 Communications } \\
\text { (Art Units 2600-2697) }\end{array}$ & $11 \%$ & $19 \%$ & $28 \%$ \\
\hline $\begin{array}{l}\text { 2800 Semiconductors, Electrical } \\
\text { and Optical Systems and } \\
\text { Components } \\
\text { (Art Units 2800-2891) }\end{array}$ & & $14 \%$ & $25 \%$ \\
\hline $\begin{array}{l}\text { 3600 Transportation, } \\
\text { Construction, Electronic } \\
\text { Commerce, Agriculture, National } \\
\text { Security and License and Review } \\
\text { (Art Units 3610-3683) }\end{array}$ & $10 \%$ & $11 \%$ & $20 \%$ \\
\hline $\begin{array}{l}\text { 3700 Mechanical Engineering, } \\
\text { Manufacturing, and Products } \\
\text { (Art Units 3700-3767) }\end{array}$ & $17 \%$ & & \\
\hline
\end{tabular}

The use of continuations of any type, displayed in the last column, varied from a low of $19.9 \%$ of applications in the transportation industry to a high of $42.6 \%$ in biotechnology. What is notable here is not only the variation across fields - the highest mean is more than twice the lowestbut that even the industries with relatively little use of continuations use them as much or more 
than the average industry did 15 years ago, at least as far as we can tell based on data from patent grants. ${ }^{21}$

The industries that use traditional continuations generally track our expectations-they were most common in the chemical and biotechnological industries, where obtaining patent protection quickly is less important. By contrast, RCEs were more common in the computer and communications industries, where applicants were two to three times more likely to use RCEs than to use continuations, perhaps reflecting their "need for speed" given shorter product lifecycles. $^{22}$

We also see cross-field differences in the types of traditional continuations used, in Table 14.

Table 14: Share of applications with continuations, CIPs, and divisionals, by USPTO Art Unit

\begin{tabular}{|l|l|l|l|}
\hline Art Unit & $\begin{array}{l}\text { Share with } \\
\text { Continuations }\end{array}$ & Share with CIPs & $\begin{array}{l}\text { Share with } \\
\text { Divisionalsvisionals }\end{array}$ \\
\hline $\begin{array}{l}\mathbf{1 6 0 0} \text { Biotechnology and Organic } \\
\text { Chemistry } \\
\text { (Art Units 1600-1661) }\end{array}$ & $10.4 \%$ & $5.4 \%$ & $12.2 \%$ \\
\hline $\begin{array}{l}\mathbf{1 7 0 0} \text { Chemical and Materials } \\
\text { Engineering } \\
\text { (Art Units 1700-1775) }\end{array}$ & $5.3 \%$ & $4.6 \%$ & $11.1 \%$ \\
\hline $\begin{array}{l}\mathbf{2 1 0 0} \text { Computer Architecture, } \\
\text { Software, \& Information Security } \\
\text { (Art Units 2100-2195) }\end{array}$ & $5.1 \%$ & $2.1 \%$ & $2.1 \%$ \\
\hline $\begin{array}{l}\mathbf{2 6 0 0} \text { Communications } \\
\text { (Art Units 2600-2697) }\end{array}$ & $4.2 \%$ & $2.3 \%$ & $2.9 \%$ \\
\hline $\begin{array}{l}\mathbf{2 8 0 0} \text { Semiconductors, Electrical } \\
\text { and Optical Systems and } \\
\text { Components } \\
\text { (Art Units 2800-2891) }\end{array}$ & $4.8 \%$ & $2.2 \%$ & $8.7 \%$ \\
\hline $\begin{array}{l}\mathbf{3 6 0 0} \text { Transportation, } \\
\text { Construction, Electronic }\end{array}$ & $3.5 \%$ & $3.1 \%$ & $3.0 \%$ \\
\hline
\end{tabular}

${ }^{21}$ See Graham \& Mowery, supra note 15, at 450 (reporting that approximately $20 \%$ of applicants across all industries used continuations in 1990).

${ }^{22}$ It is worth noting, however, that the biotechnology industry was also one of the largest users of RCEs. 


\begin{tabular}{|l|l|l|l|}
\hline $\begin{array}{l}\text { Commerce, Agriculture, National } \\
\text { Security and License and Review } \\
\text { (Art Units 3610-3683) }\end{array}$ & & & \\
\hline $\begin{array}{l}\text { 3700 Mechanical Engineering, } \\
\text { Manufacturing, and Products } \\
\text { (Art Units 3700-3767) }\end{array}$ & & & \\
\hline
\end{tabular}

The differences here are dramatic-biotechnology and chemical applicants are far more likely to file divisionals than are companies in any other industry. This is consistent with anecdotal evidence suggesting that the PTO is imposing restriction requirements with abandon in those industries, forcing applicants to divide their patent applications multiple ways. ${ }^{23}$

\section{Conclusion}

The evidence illuminates the patent prosecution process as a continuing negotiation between examiner and applicant. That negotiation does not end with an initial or even a final rejection. Interviews and amendments after final rejection play an extremely significant role in generating patents, and in limiting the scope of those claims as well. Nor is that the end of the process. Continuation applications are flourishing. They have broken into two roughly equal groups, with different uses. Many applicants are using RCEs to keep fighting for claims that the examiner was not willing to give them. Others file continuation applications rather than RCEs. These applicants have opted for a slower process, either because they want delay so that they can modify their applications to track developments in the marketplace or because they want multiple patents to build an effective fence around a single invention.

\footnotetext{
${ }^{23}$ See, e.g., Teresa J. Welch, When One Patent Application Begets 10: Today's Hyperproliferative U.S. Restriction Practice, INTELL. PROP. STRATEGIST, JAN. 1, 2004, http://www.lawjournalnewsletters.com/issues/ljn_intproperty/10_4/news/141833-1.html ("In recent years, hyperproliferation of restriction requirements, especially in the biotechnology, chemical and software arts, has occurred.").
} 